TAO, Vol. 16, No. 2, 513-528, June 2005

\title{
A Case Study of System and Planktonic Responses in a Subtropical Warm Plume Receiving Thermal Effluents from a Power Plant
}

\author{
Fuh-Kwo Shiah ${ }^{1,2, *}$, Yueh-Yuan Tu ${ }^{3}$, Hsien-Shiow Tsai ${ }^{3}$, Shuh-Ji Kao ${ }^{1}$ and Sen Jan ${ }^{4}$
}

(Manuscript received 1 October 2004, in final form 3 May 2005)

\begin{abstract}
To explore planktonic and ecosystem responses to thermal effluents of a power plant, three transect surveys were conducted in Nov-01', May-02' and Jun-02' at the bay adjacent to the outlet of Taiwan Nuclear Power Plant II. At the given station, seasonal trends were evident with most maximal measurements observed in Jun-02'. Physical mixing between background seawater and thermal effluents played an important role in determining planktonic biomass since chlorophyll $\left(\mathrm{Chl},<0.15-1.27 \mathrm{mgChl} \mathrm{m}^{-3}\right)$ and bacterial biomass (BB, $11-48 \mathrm{mgC} \mathrm{m}^{-3}$ ) increased almost linearly seaward. Temperature $\left(20-45^{\circ} \mathrm{C}\right)$ manipulation experiments suggested that phytoplankton were more vulnerable than heterotrophs to thermal stress. Differential temperature responses of auto- and heterotrophs result in primary production $\left(\mathrm{PP},<1-100 \mathrm{mgC} \mathrm{m}^{-3} \mathrm{~d}^{-1}\right)$ increasing seaward, while community respiration $\left(\mathrm{CR}, 15-68 \mathrm{mgC} \mathrm{m}^{-3} \mathrm{~d}^{-1}\right)$ and bacterial growth rate (BGR, $0.03-0.9 \mathrm{~d}^{-1}$ ) showed opposite trends. The plume system was heterotrophic $(\mathrm{PP} / \mathrm{CR}$ ratio $<1)$ in areas with bottom depths ca. $<10 \mathrm{~m}$, and then switched to autotrophic status $(\mathrm{PP} / \mathrm{CR}$ ratio $>1-3.7)$ in deeper regions. High observed dissolved organic carbon (DOC) anomaly (23 - 34 $\mathrm{gC} \mathrm{m}^{-3}$ ) implied that heterotrophic metabolism was seldom limited by bottom-up control processes. Short-term manipulation experiments showing that $\mathrm{BGR}$ and $\mathrm{CR}$ increased with rising temperature up to ca. $37^{\circ} \mathrm{C}$, which was $\sim 12^{\circ} \mathrm{C}$ higher than frequently reported values from most coastal and estuarine ecosystems. We ascribed this to the effects of temperature-substrate interaction. The results of organic carbon (zooplankton extract) ad-
\end{abstract}

\footnotetext{
${ }^{1}$ Research Center for Environmental Changes, Academia Sinica, Taipei, Taiwan, ROC

2 Institute of Marine Environmental Chemistry and Ecology, National Taiwan Ocean University, Keelung, Taiwan, ROC

3 Department of Industrial Safety and Environmental Protection, Taiwan Power Company

4 Institute of Hydrological Sciences, National Central University, Chung-Li, Taiwan, ROC

* Corresponding author address: Prof. Fuh-Kwo Shiah, Research Center for Environmental Changes, Academia Sinica, Taipei, Taiwan, ROC;E-mail: fkshiah@gate.sinica.edu.tw
} 
dition experiments suggested a certain fraction of the in situ DOC was as labile as animal tissue since the increasing trends of BGR in the enriched and control treatments behaved similarly. From a carbon cycling perspective, the positive temperature responses of heterotrophic activities imply that in coastal systems with a high loading of anthropogenic DOC, the biogenic emission rate of $\mathrm{CO}_{2}$ might increase exponentially as global temperatures rise.

(Key words: Phytoplankton, Primary production, Bacteria, Community respiration, Temperature, $Q_{10}$ )

\section{INTRODUCTION}

Studies on planktonic tropho-dynamics based on ecosystem perspectives have become very popular since the eighties. Research results derived from natural ecosystems have greatly increased our understanding of biogeochemical processes occurring within and between systems. As a result of increasing anthropogenic activities, many coastal systems are becoming subject to human disturbance. A study of behaviors such as one on biomass and rate parameters of various plankters in a highly disturbed system might serve as a good reference point for our current understanding of carbon cycling and planktonic tropho-dynamics.

One of the environmental issues caused by the operation of nuclear power plants is their potential thermal stress on aquatic organisms living nearby. In Taiwan, several cases such as that of the "malformed fish" (Hung et al. 1998) and coral bleaching (Dai 1999) have been reported as resulting from the thermal effluents of power plants. Related studies of thermal stress on planktonic activities have been conducted elsewhere, but with limited measurements focusing only on one or two individual processes. For example, Servais and Billen (1989) studied thermal effects on primary and bacterial production. Choi et al. (2002) studied thermal stress and its effects on the activity of heterotrophic bacterioplankton and nanoflagellates. System characteristics such as the ratio of primary production to community respiration i.e. the P/R (or PP/CR) ratio were not analyzed in both studies. Moreover, these two (and most relevant) studies were conducted in temperate regions with maximal temperature $<30^{\circ} \mathrm{C}$. Temperature responses of planktonic activity in the thermal plume at temperature $>30^{\circ} \mathrm{C}$ remain unexplored. This study was designed to understand the controlling mechanisms over the seasonal and temporal variations of autotrophic and heterotrophic processes as well as system characteristics in a subtropical warm plume system adjacent to the Tai-Power power plant.

\section{MATERIALS AND METHODS}

\subsection{Study Site and Sampling}

Three transect surveys were conducted in Nov-01', May-02'and Jun-02' at the bay adja- 


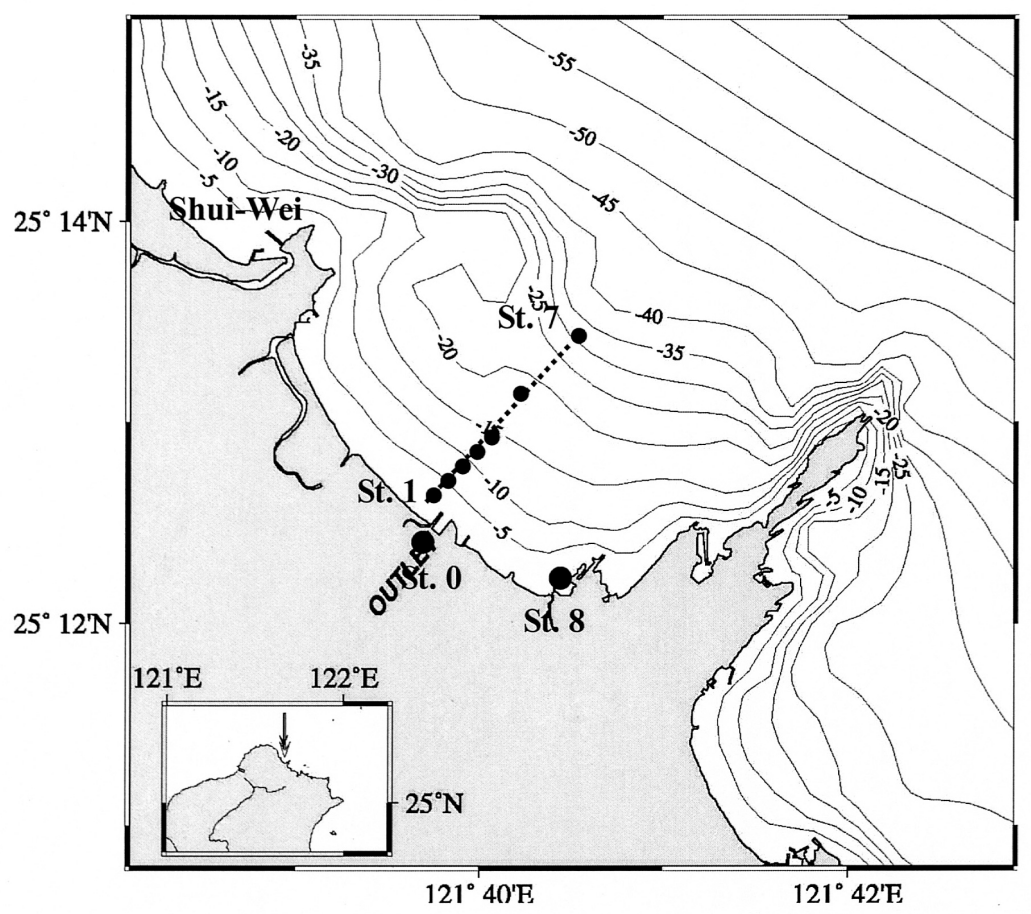

Fig. 1. Map of the Taiwan Nuclear Power Plant II showing sampling stations at the inlet (St. 8), outlet (St. 0) and transect (Sts. 1 7). Dash lines indicate bottom depth in meters.

cent to the outlet of Taiwan Nuclear Power Plant II (Fig. 1). Semidiurnal M2 is the dominant constituent of tides in the study area. The tidal range at spring and neap tides averages 1.25 and $0.83 \mathrm{~m}$, respectively. The tidal flushing time is $\sim 5 \mathrm{hrs}$ during flood or ebb; and the tidal residual has a residence time estimated to be $\sim 2$ days in the northwestern bay (Dr. S. Jen, Inst. Hydrography, NCU-Taiwan, personal communication).

Seven sampling stations (Sts. 1 - 7) were deployed along the transect encompassing the warm water plume. Measurements at the inlet (St. 8) and outlet (St. 0) were also conducted concomitantly. All 3 transect studies were conducted via fishing boat ( 50 tons) during the daytime within the same tidal amplitude i.e., the neap tide. Temperatures were recorded with a SeaBird CTD (SBE 9/11+, SBE Inc. USA). Surface waters were sampled with 5.0 Go-Flo bottles and stored in 20L pre-acid washed opaque PC bottles. It took $\sim 1 \mathrm{hr}$ to complete each sampling at sea and another $1 \mathrm{hr}$ for transportation from the Shui-Wei harbor (Fig. 1) to the laboratory for further analysis. The cruise time from the Shui-Wei harbor to the sampling site was $\sim 20$ minutes. The boat then went back to the sampling stations for primary production measurement (see below). Data of the surface photosynthetic available radiance (PAR) were taken from the Central Weather Bureau-Taiwan. 


\subsection{Inorganic Nutrients, Chlorophyll and Primary Production}

Nutrient (nitrate) and chlorophyll concentrations were measured following the method of Parsons et al. (1984). Primary production (PP) was measured by the ${ }^{14} \mathrm{C}$ assimilation method (Parsons et al. 1984) on board. In brief, two light and one dark $250 \mathrm{~mL}$ clean PC bottles were filled with water samples. After inoculation with $\mathrm{H}^{14} \mathrm{CO}_{3}^{-}$(final conc., $10 \mu \mathrm{Ci} \mathrm{ml}{ }^{-1}$ ), samples were wrapped with 10 neutral density filters (LEE filters, 0, 6, 12, 16, 23, 36, 44, 63, 91 \& $100 \%$ ) and incubated for 20 minutes in a self-designed tank with an artificial light source $\left(\sim 2000 \mu \mathrm{E} \mathrm{m}^{-2} \mathrm{~s}^{-1}\right)$. The boat anchored at each station when incubation was performed. For temperature control, the tank was filled with running seawater from that specific station. Following retrieval, samples were filtered through GF/F filters on board. The filters were then placed in scintillation vials, and $0.5 \mathrm{ml}$ of $0.5 \mathrm{~N} \mathrm{HCl}$ was added to remove residual $\mathrm{H}^{14} \mathrm{CO}_{3}^{-}$. Radioactivity was counted in a liquid scintillation counter (Packard 1600) after the addition of a $10 \mathrm{ml}$ scintillation cocktail (Ultima Gold, Packard) into the vials. The Webb et al. (1974) $\mathrm{P}^{\mathrm{B}}$-E model was applied to estimate the maximal Chl normalized photosynthetic rate $\left(\mathrm{P}^{\mathrm{B}}{ }_{\max }\right)$ and the initial slope. Daily PP then estimated with the values $\mathrm{P}^{\mathrm{B}}{ }_{\max }$, initial slope, $\mathrm{Chl}$ and daytime surface PAR.

\subsection{Particulate and Dissolved Organic Carbon Concentrations}

Samples for particulate organic carbon (POC) were filtered through Whatman GF/F filter pre-combusted at $550^{\circ} \mathrm{C}$. After drying and acid-fuming, samples were measured by the combustion method (HORIBA EMIA-510). Samples for dissolved organic carbon (DOC) measurement were filled into pre-combusted $40 \mathrm{ml}$ vials. After the addition of several drops of $80 \% \mathrm{H}_{3} \mathrm{PO}_{4}$, vials were sealed with pre-combusted aluminum foil and screw caps with Tefloncoated septa. Before analysis, samples were acidified with $80 \% \mathrm{H}_{3} \mathrm{PO}_{4}$ and sparged with $\mathrm{CO}_{2}$-free $\mathrm{O}_{2}$ at a flow rate of $350 \mathrm{~mL} / \mathrm{min}$ for $>10$ mins. Samples were analyzed by high temperature catalytic oxidation method with a SHIMADZU, TOC 5000. All samples were blank (20 - $25 \mu \mathrm{M})$ corrected and double-checked with deep seawater $(\sim 3000 \mathrm{~m})$ from the South China Sea (DOC $\sim 50 \mu \mathrm{M})$.

\subsection{Community Respiration Rate}

Field measurements of micro-plankton community respiration rates (CR) were measured by the decrease of $\mathrm{O}_{2}$ concentrations. In brief, $200 \mu$ mesh filtrates (remove macro-zooplankton) were filled into Wheaton $500 \mathrm{~mL}$ DO bottles. Dark incubation was performed at in situ temperature for $6 \sim 12 \mathrm{hrs}$. Initial and final $\mathrm{O}_{2}$ concentrations were measured by the Shibala method (Pai et al. 1993). A molar ratio of $\mathrm{O}_{2}: \mathrm{CO}_{2}=138: 106$ (Redfield et al. 1963) was used to convert $\mathrm{O}_{2}$ into carbon units.

\subsection{Bacterial Biomass, Production and Growth Rate}

Bacterial abundance in the field was estimated by the Acridine Orange Direct Count method 
(Hobbie et al. 1977) with Epi-fluorescence microscope (Axioplan 2, Zeiss). Field measurement of bacterial activity was measured by ${ }^{3} \mathrm{H}$-thymidine incorporation (Fuhrman and Azam 1982). Bacterial biomass (BB) and production (BP) in $\mathrm{C}$ units were derived with a thymidine and a carbon conversion factor of $1.8 \times 10^{18}$ cell mole $^{-1}$ and $2 \times 10^{-14} \mathrm{gC} \mathrm{cell}^{-1}$ respectively. Details see Shiah et al. (2003a). Bacterial growth rates were calculated by dividing BP with BB.

\subsection{Temperature Effects on Photosynthetic Parameters and Heterotrophic Activity}

Water samples from the inlet were collected in Dec-01', Mar-02' and Aug-02' and stored in $20 \mathrm{~L}$ pre-acid washed opaque PC bottles, and then brought back to the laboratory for further analysis. In the photosynthetic parameter experiments, $200 \mu$ mesh filtered water samples wrapped with 9 neutral density filters were pre-incubated $1 \mathrm{hr}$ in 5 temperature treatments ranging $20-45^{\circ} \mathrm{C}$ in the self-designed incubation tanks. During light incubation period (20 minutes), temperature was checked every 5 minutes, and maintained by adding ice into the tanks. Initial slope and $\mathrm{P}^{\mathrm{B}}{ }_{\text {max }}$ were derived by the $\mathrm{H}^{14} \mathrm{CO}_{3}{ }^{-}$incorporation method described above. For heterotrophic activity experiments, $200 \mu$ mesh filtered water samples in triplicate $2 \mathrm{~L} \mathrm{PC}$ bottles were pre-incubated $1 \mathrm{hr}$ in the 5 temperature treatments described above. BP and $\mathrm{CR}$ were measured after $6-12$ hrs dark incubation. POC concentrations and BB for the Dec-01', Mar-02' and Aug-02' experiments were 102, 121 and $154 \mathrm{mgCm}^{-3}$ as well as 43, 42 and $44 \mathrm{mgC} \mathrm{m}^{-3}$, respectively.

\subsection{Zooplankton Extract Enrichment Effects on Bacterial Growth}

Inlet seawaters collected in May-02' were filtered through $0.8 \mu, 105 \mathrm{~mm}$ pre-combusted $\mathrm{GF} / \mathrm{F}$ filters to removed bacterivores including flagellates and ciliates. The filtrates were assigned to 6 treatments in $2 \mathrm{~L} \mathrm{PC}$ bottles. Four of them were the control treatments and incubated at $25^{\circ} \mathrm{C}$ and $35^{\circ} \mathrm{C}$ with duplicates of each. Zooplankton extract (freshly collected zooplankton at the inlet were homogenized by grinding and then filtered through GF/F filters) was added into the other two treatments and defined as enriched treatment. The final added concentration of the extract was $\sim 24 \mathrm{gC} \mathrm{m}^{-3}$. The enriched treatments then were incubated at $25^{\circ} \mathrm{C}$ and $35^{\circ} \mathrm{C}$ with no duplicates. BP was measured approximately every 6 hours for 24 hours.

\section{RESULTS}

\subsection{Transect Study}

Data from the 3 transect studies showed a distinct spatial pattern with noticeable seasonal traits. Measurements between St. 0 (outlet) and St. 1 were very similar. This was also true for those between St. 8 (inlet) and St. 7. The latter two stations were defined as the background seawater. We described the results from St. 1 to 7 as follows. All nine stations results were included in later statistical analysis. The highest water temperatures were always recorded at 
St. 1 which was located $\sim 500 \mathrm{~m}$ outside the outlet, temperature then decreased seaward (Fig. 2A). For any given season, temperature difference between Sts. 1 and 7 was about $8^{\circ} \mathrm{C}$. Nitrate concentrations $\left(\mathrm{NO}_{3}\right)$ were high $(>5.0 \mu \mathrm{M}$, Fig. $2 \mathrm{~B})$ in Nov-01' but with no distinct spatial pattern. These decreased down to $<3.0 \mu \mathrm{M}$ in May-02' and Jun-02', particularly at the offshore stations. Particulate organic carbon concentrations (POC, Fig. 2C, $66-181 \mathrm{mgC} \mathrm{m}^{-3}$ ) were lower in Nov-01' and decreased offshore, while the spatial patterns for the POC recorded in the other two cruises were not significant. Dissolved organic carbon concentrations (DOC, Fig. 2D, $23-34 \mathrm{gC} \mathrm{m}^{-3}$ ) did not vary much in May-02' and Jun-02'. However, DOC concentrations decreased offshore reaching a minimum at St. 4 and then increased at St. 6 in Jun-02'.

Chlorophyll concentrations ( $\mathrm{Chl},<0.15-1.27 \mathrm{mgChl} \mathrm{m}^{-3}$, Fig. 2E) increased seaward in all 3 surveys. Spatial patterns of $\mathrm{Chl}$ in Nov-01' and May-02' were quite similar with maximal value $<1.0 \mathrm{mgChl} \mathrm{m}{ }^{-3}$, while Chl recorded in Jun-02' at Sts. $6-7\left(>1.25 \mathrm{mgm}^{-3}\right)$ were higher than the 2 previous surveys. Initial slopes (Fig. $2 \mathrm{~F}, 0.001-0.014 \mathrm{gChl}^{-1} \mathrm{~h}^{-1} \mu \mathrm{E}^{-1} \mathrm{~m}^{-2} \mathrm{~s}^{-1}$ ), Chl normalized maximal primary production ( $\mathrm{P}_{\text {max }}^{\mathrm{B}}$, Fig. $2 \mathrm{G}, 1.2-11.4 \mathrm{gC} \mathrm{gChl}^{-1} \mathrm{~h}^{-1}$ ) and primary production (PP, Fig. $2 \mathrm{H},<1-100 \mathrm{mgC} \mathrm{m}^{-3} \mathrm{~d}^{-1}$ showed the same spatial and seasonal patterns; they were high in Jun-02' but low in Nov-01' with a common trend of increasing seaward.

Temporal variation of community respiration (CR, Fig. 2I, $15-68 \mathrm{mgC} \mathrm{m}^{-3} \mathrm{~d}^{-1}$ ) derived from the 3 studies behaved similarly to those of PP, but with a decreasing trend seaward. Higher values of CR and NCR (POC normalized CR) were always recorded in Jun-02'. Ratios of PP/CR varied more than 300-fold $(<0.01-3.7$, Fig. $2 \mathrm{~J})$ with lower values at near-shore stations and then increased seaward with values $>1$ beyond St. 5. At any given station, cold season (Nov-01') had higher PP/CR ratios than warm periods (Mar-02' and Jun-02'). Bacterial production (BP, Fig. 2K) measurements in Nov-01' and May-02' were low $\left(<1-3 \mathrm{mgC} \mathrm{m}{ }^{-3} \mathrm{~d}^{-1}\right)$ and varied insignificantly among stations. In Jun-02', BP $\left(10-26 \mathrm{mgC} \mathrm{m}^{-3} \mathrm{~d}^{-1}\right)$ increased seaward by $>2$-fold when compared with the previous two cruises. Bacterial biomass (BB, Fig. 2L, $11-48 \mathrm{mgC} \mathrm{m}^{-3}$ ) in all 3 surveys increased seaward; however, bacterial growth rates (BGR, Fig. 2M, $0.03-0.9 \mathrm{~d}^{-1}$ ) were increasing offshore with higher values recorded in Jun02'.

Table 1 indicated the results of correlation analysis. Autotrophic measurements including $\mathrm{Chl}, \mathrm{P}_{\text {max }}^{\mathrm{B}}$, initial slope and $\mathrm{PP}$ were negatively correlated with temperature, while CR correlated positively with temperature. Bacteria measurements were inconsistent between biomass and rate parameters. BP and BB showed negative trends with temperature while BGRs were positively correlated with temperature. $\mathrm{PP}$ and $\mathrm{Chl}$ values were positively correlated with $\mathrm{BP}$ and $\mathrm{BB}$, but it co-varied negatively with BGR. The PP/CR ratios were negatively correlated with temperature and $\mathrm{CR}$, but varied positively with autotrophic measurements. Temperature responses of BGR and CR of these 3 studies were shown in Table 2. The $\mathrm{Q}_{10}$ (the increase of metabolic rate for a temperature of $10^{\circ} \mathrm{C}$ rising) values for them ranged $1.8-3.3$.

\subsection{Effects of Temperature Manipulation and Zooplankton Extract Enrichment}

In the 3 temperature manipulation experiments, values of initial slope and $\mathrm{P}^{\mathrm{B}}{ }_{\max }$ (Figs. $3 \mathrm{~A}, \mathrm{~B})$ did not show much difference within each treatment at temperatures of $20-30^{\circ} \mathrm{C}$. 

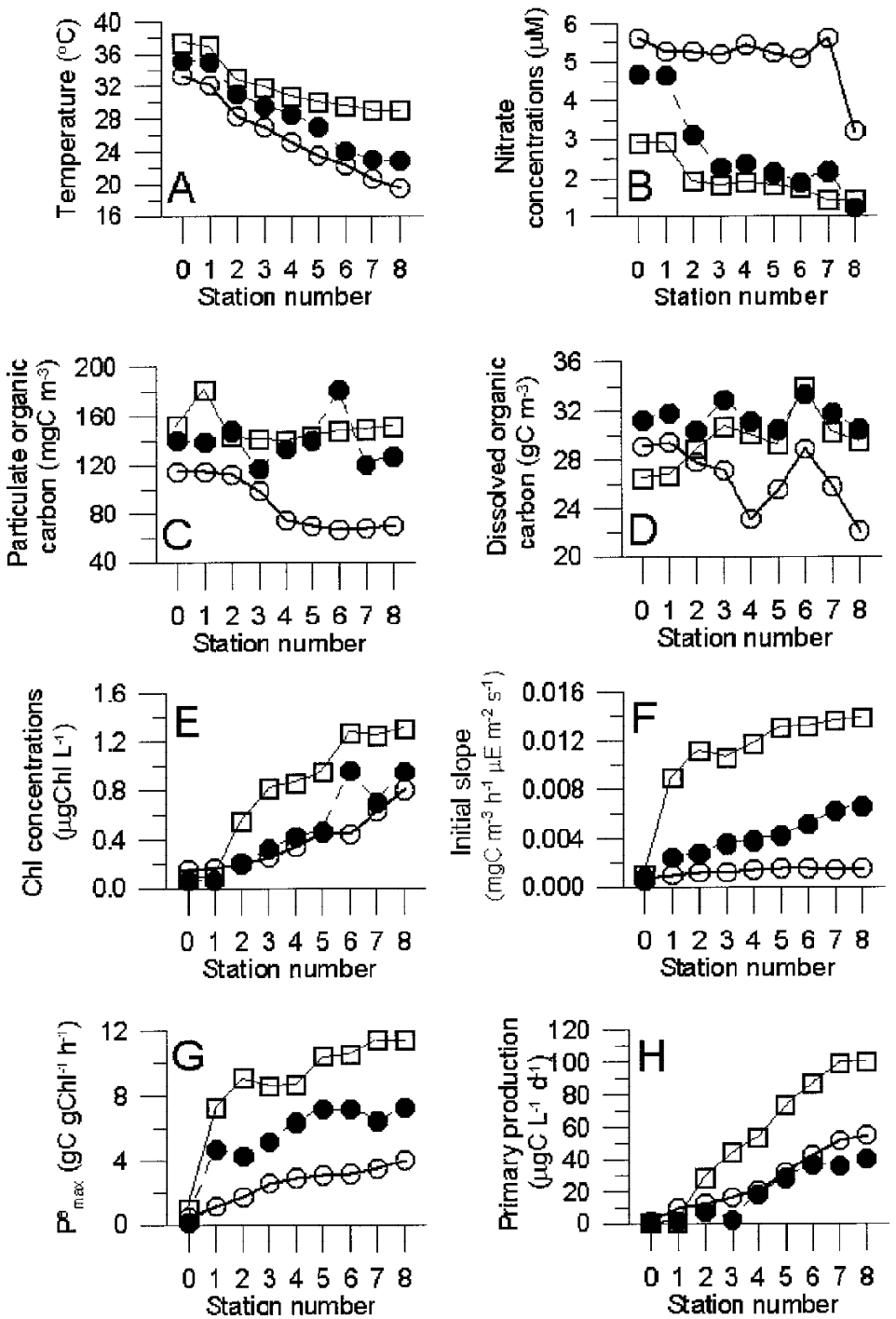

Fig. 2. Spatial variation of measurements taken from the transect study of Nov01' (open circles, thick line), May-02' (solid circles, dash line) and Jun02 ' (open squares). Numerical of $\mathrm{X}$ - axis indicates sampling stations (see also Fig. 1). (A) temperature, (B) nitrate concentrations, (C) particulate organic carbon concentrations, (D) dissolved organic carbon concentrations, (E) chlorophyll-a concentrations, (F) initial slopes $(G)$ chlorophyll-a normalized maximal photosynthetic rates, $(\mathrm{H})$ primary production, (I) community respiration rate, $(\mathrm{J})$ ratio of primary production to community respiration, $(\mathrm{K})$ bacterial production, $(\mathrm{L})$ bacterial biomass and (M) bacterial growth rate. 

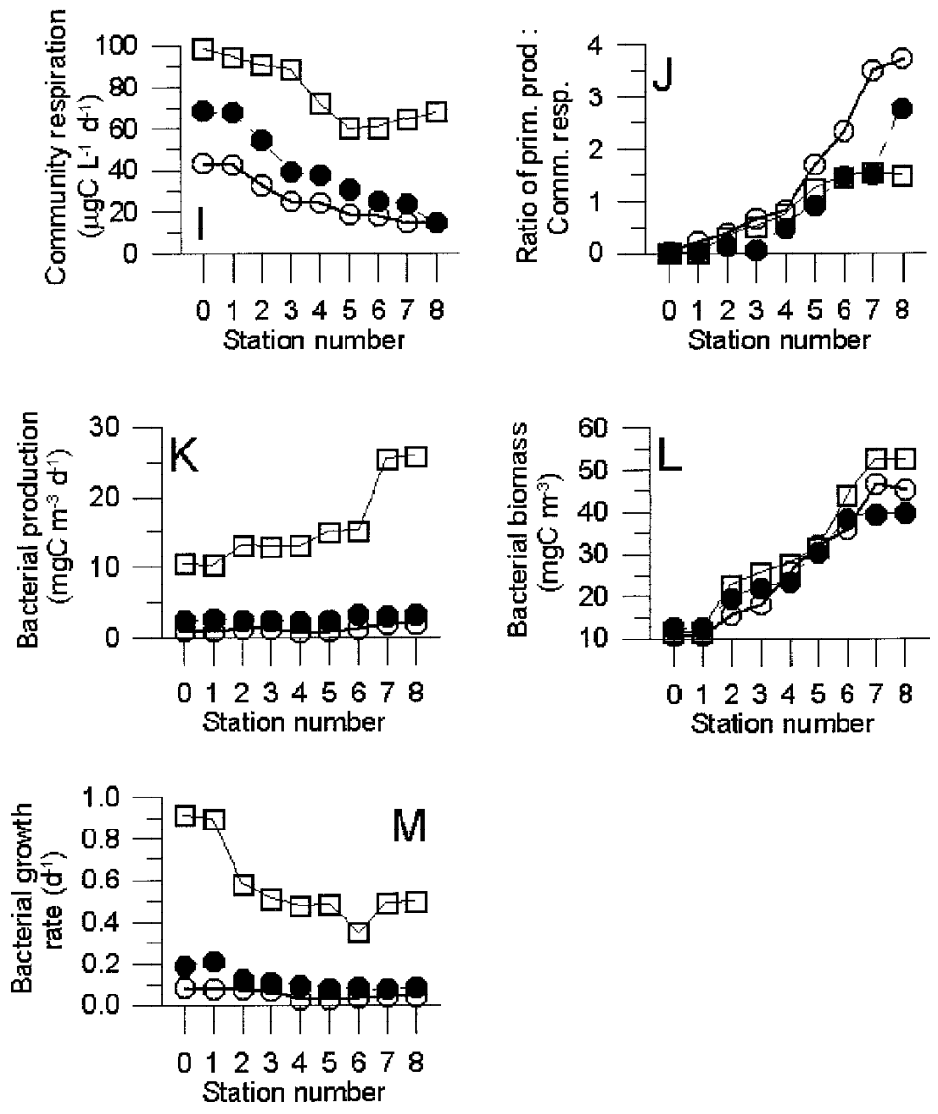

Fig. 2. Continued.

These two parameters reduced significantly at temperatures $>37^{\circ} \mathrm{C}$. Noted that at given temperature treatment, the highest values of initial slope and $\mathrm{P}^{\mathrm{B}}{ }_{\text {max }}$ appeared in the Aug-02' experiment. For heterotrophic parameters, POC normalized community respiration (NCR, Fig. 3C) and BGR (Fig. 3D) showed an Arrhenius-type expression. That is, these rate parameters increased exponentially with rising temperature up to $38^{\circ} \mathrm{C}$, and then decreased significantly at $45^{\circ} \mathrm{C}$. Temperature responses of $\mathrm{CR}$ and $\mathrm{BP}$ (data not shown) were the same as those of BGR and NCR. Within the temperature range of $20-38^{\circ} \mathrm{C}$, the $\mathrm{Q}_{10}$ values of $\mathrm{CR}, \mathrm{NCR}, \mathrm{BP}$ and BGR varied within a narrow range of 2.7 - 3.3 (Table 2). When incubated at the same temperature, the addition of zooplankton extract seemed to have no effect on BP when compared with those of the controls (Fig. 4). On the other hand, BP under higher incubation temperature $\left(35^{\circ} \mathrm{C}\right)$ elevated at a rate faster than those of $25^{\circ} \mathrm{C}$ treatments after 6 hours incubation.

\section{DISCUSSIONS AND CONCLUSIONS}

Temperature variation in the plume indicated not only the physical conditions for plank- 
Table 1. Correlations of temperature (T) and primary production (PP) vs. the other measurements ${ }^{@}$ of the three transect studies. ns, not significant at $\mathrm{p}=0.05$ level; symbol “-”, not analyzed.

\begin{tabular}{|c|c|c|c|c|c|c|}
\hline \multirow[t]{2}{*}{ Items } & \multirow{2}{*}{$\begin{array}{c}\text { Nov-01' } \\
T\end{array}$} & \multicolumn{2}{|c|}{ May-02' Jun-02' } & \multirow{2}{*}{$\begin{array}{l}\text { Nov-01' } \\
\text { PP }\end{array}$} & \multirow{2}{*}{$\begin{array}{c}\text { May-02' } \\
\text { PP }\end{array}$} & \multirow{2}{*}{$\begin{array}{c}\text { Jun-02' } \\
\text { PP }\end{array}$} \\
\hline & & $\mathbf{T}$ & $\mathbf{T}$ & & & \\
\hline Nitrate & ns & +0.93 & +0.97 & ns & -0.80 & -0.91 \\
\hline Particulate organic carbon & +0.93 & ns & ns & -0.88 & ns & ns \\
\hline Dissolved organic carbon & +0.68 & ns & -0.77 & ns & ns & +0.70 \\
\hline Chlorophyll (Chl) & -0.93 & -0.95 & -0.98 & - & - & - \\
\hline Chl nor. maximal production & -0.98 & -0.81 & -0.87 & - & - & - \\
\hline Initial slope & -0.95 & -0.96 & -0.87 & - & - & - \\
\hline Primary production (PP) & -0.96 & -0.94 & -0.96 & - & - & - \\
\hline Community respiration (CR) & +0.98 & +0.98 & +0.90 & -0.91 & -0.91 & -0.92 \\
\hline $\mathrm{PP} / \mathrm{CR}$ ratio & -0.92 & -0.87 & -0.93 & +0.99 & +0.92 & +0.99 \\
\hline Bacterial production & -0.73 & -0.70 & -0.72 & +0.82 & +0.78 & +0.84 \\
\hline Bacterial biomass & -0.96 & -0.99 & -0.90 & +0.99 & +0.96 & +0.97 \\
\hline Bacterial growth rate & +0.84 & +0.90 & +0.95 & -0.74 & -0.78 & -0.85 \\
\hline
\end{tabular}

tonic growth but also the magnitude of mixing between background seawater and thermal effluents. The plume system itself can be viewed as gradients of physical and chemical processes, which might ultimately affect the variation of auto- and hetero-trophic processes. The thermal effluents came out of the outlet (at St. 0) containing high temperature seawater with very low planktonic biomass and activity as these had been greatly reduced via the cooling and electrolysis processes of the power plant (Choi et al. 2002). However, once in the plume system, background seawater and its accompanying live organisms were mixed into the water column. Thermal stress at St. 1 (i.e., $32-37^{\circ} \mathrm{C}$ ) possibly still acted upon autotrophs (Figs. 3A, B) but probably not heterotrophs (Figs. 3C, D). Servias and Billen (1989) showed that bacteria could tolerate higher temperatures than phytoplankton in the Muse power plant. In an experiment conducted at the Hadong power station (Korea), Choi et al. (2002) demonstrated that a temperature of $40^{\circ} \mathrm{C}$ inhibited BP by $23-69 \%$ but had no effect on heterotophic nanoflagellates, indicating that larger heterotrophs might be able to endure higher magnitudes of thermal stress than bacteria.

Similarly, our study showed the reduction of $\mathrm{P}^{\mathrm{B}}{ }_{\max }$ (and initial slope, too) occurred at temperatures lower than those of BGR and NCR (Figs. 3A, D). As temperature dropped below ca. $30^{\circ} \mathrm{C}$, the values of $\mathrm{P}^{\mathrm{B}}{ }_{\text {max }}$ soon recovered to a level similar to those of the background seawaters (Figs. 2F, G; Fig. 3A, B). Noted also that $\mathrm{P}^{\mathrm{B}}{ }_{\max }$ did not change much at tempera- 

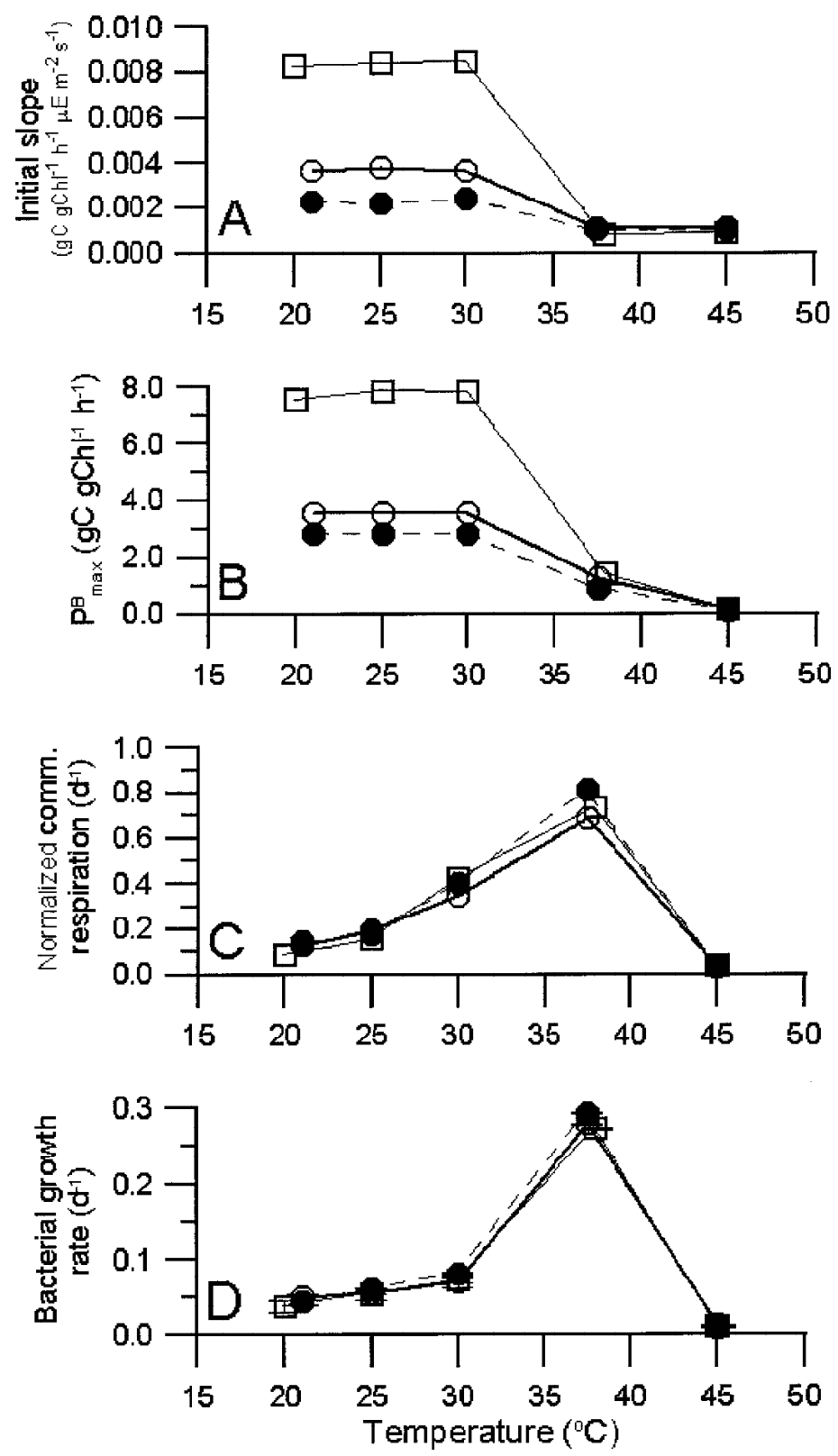

Fig. 3. Temperature effects on (A) the initial slopes, (B) Chl-a normalized maximal photosynthetic rates - $\mathrm{P}^{\mathrm{B}}{ }_{\max }$ (C) POC normalized community respiration rate and (D) bacterial growth rate. Symbol for the Dec-01', Mar02' and Aug-02' are shown in open circles, solid circles and open squares respectively. 
Table 2. List of the statistics for the linear regression of natural log transformed bacterial production $(\mathrm{BP})$, community respiration $(\mathrm{CR})$, bacterial growth rate (BGR) and POC normalized CR (NCR) of this study. ns, not significant at $p=0.05$ level; s.d., standard deviations; $\mathrm{R}^{2}$, coefficient of determination; $\mathrm{Q}_{10}$, the increase of rate as temperature increase $10^{\circ} \mathrm{C}$.

\begin{tabular}{|c|c|c|c|c|c|c|c|}
\hline Study type & $\begin{array}{c}\mathrm{T} \\
\text { Range } \\
\end{array}$ & \multicolumn{2}{|c|}{$\begin{array}{l}\text { dependent intercept } \\
\text { variable }\end{array}$} & slope $^{\#}$ ( \pm s.d.) & $\begin{array}{c}\text { sampling } \\
\text { size } \\
\end{array}$ & $\mathrm{R}^{2}$ & $\mathrm{Q}_{10}$ \\
\hline Transect & & $\operatorname{Ln} B P$ & & $\mathrm{~ns}$ & 9 & & \\
\hline \multirow[t]{2}{*}{ November, 2001} & $21 \sim 32$ & $\operatorname{Ln} C R$ & +0.81 & $+0.09( \pm 0.007)$ & 9 & 0.98 & 2.5 \\
\hline & & Ln BGR & -4.27 & $+0.11( \pm 0.019)$ & 9 & 0.86 & 3.0 \\
\hline Transect & & $\mathrm{Ln} B P$ & & ns & 9 & & \\
\hline \multirow[t]{2}{*}{ May, 2002} & $23 \sim 35$ & $\operatorname{Ln} C R$ & +1.03 & $+0.09( \pm 0.007)$ & 9 & 0.97 & 2.5 \\
\hline & & Ln BGR & -3.58 & $+0.09( \pm 0.010)$ & 9 & 0.94 & 2.5 \\
\hline Transect & & Ln BP & & ns & 9 & & \\
\hline \multirow[t]{2}{*}{ June, 2002} & $29 \sim 37$ & $\operatorname{Ln} C R$ & +1.67 & $+0.06^{\#}( \pm 0.017)$ & 9 & 0.71 & 1.8 \\
\hline & & Ln BGR & -4.42 & $+0.12(+0.015)$ & 9 & 0.92 & 3.3 \\
\hline T. manipulation & $21 \sim 37$ & Ln BP & -0.23 & $+0.10( \pm 0.027)$ & $12^{(1)}$ & 0.86 & 2.7 \\
\hline \multirow[t]{3}{*}{ December, 2001} & & Ln CR & +0.43 & $+0.10( \pm 0.005)$ & 12 & 0.99 & 2.7 \\
\hline & & Ln BGR & -4.01 & $+0.10( \pm 0.026)$ & 12 & 0.88 & 2.7 \\
\hline & & Ln NCR & -4.12 & $+0.10( \pm 0.004)$ & 12 & 0.99 & 2.7 \\
\hline T. manipulation & $21 \sim 37$ & Ln BP & -0.55 & $+0.11( \pm 0.019)$ & 12 & 0.95 & 3.0 \\
\hline \multirow[t]{3}{*}{ March, 2002} & & $\operatorname{Ln} C R$ & +0.45 & $+0.11( \pm 0.010)$ & 12 & 0.98 & 3.0 \\
\hline & & Ln BGR & -4.31 & $+0.12( \pm 0.018)$ & 12 & 0.95 & 3.3 \\
\hline & & Ln NCR & -4.33 & $+0.11( \pm 0.010)$ & 12 & 0.98 & 3.0 \\
\hline T. manipulation & $20 \sim 38$ & Ln BP & -0.41 & $+0.11( \pm 0.020)$ & 12 & 0.94 & 3.0 \\
\hline \multirow{3}{*}{\multicolumn{2}{|c|}{ August, 2002}} & Ln CR & +0.14 & $+0.12( \pm 0.018)$ & 12 & 0.96 & 3.3 \\
\hline & & Ln BGR & -4.22 & $+0.11( \pm 0.019)$ & 12 & 0.94 & 3.0 \\
\hline & & Ln NCR & -4.86 & $+0.12( \pm 0.018)$ & 12 & 0.96 & 3.3 \\
\hline
\end{tabular}

\#, slope is significantly different from others by Analysis of Covariance at $\mathrm{p}=0.05$ level.

@ , triplicate incubations and data of the $45^{\circ} \mathrm{C}$ treatment are excluded in analysis. 


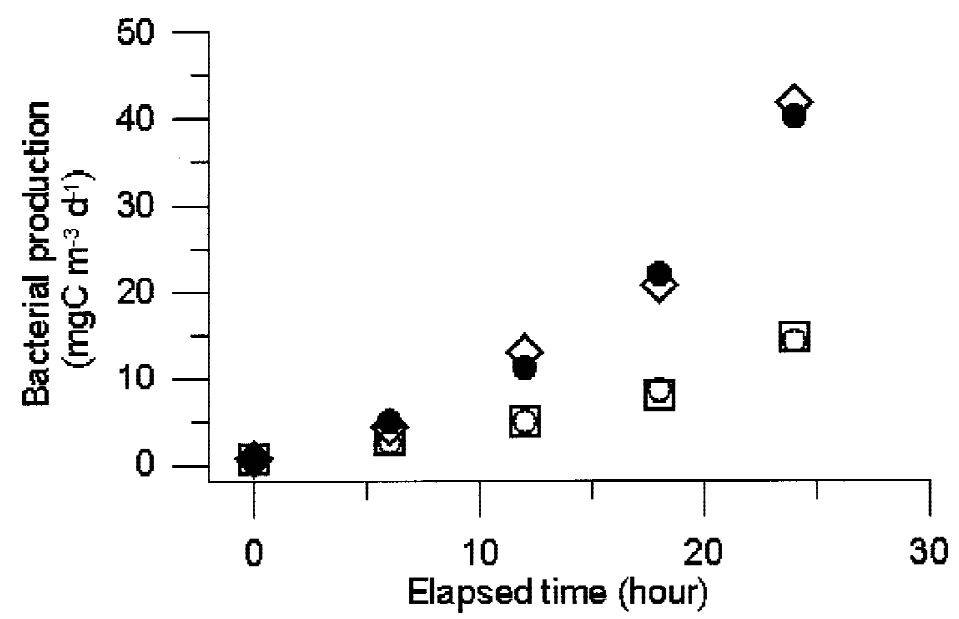

Fig. 4. Zooplankton extract enriched effects on bacterial production. Symbols open squares, open diamonds, open circles and solid circles indicate control $-25^{\circ} \mathrm{C}$, control $-35^{\circ} \mathrm{C}$, enriched $-25^{\circ} \mathrm{C}$, and enriched $-35^{\circ} \mathrm{C}$, respectively.

tures ranging $20-30^{\circ} \mathrm{C}$, but $\mathrm{CR}$ (and NCR) varied $\sim 3$-fold at this temperature range in the manipulation experiments. Such differential temperature response of auto- and heterotrophic rates explains why the PP/CR ratios increased offshore (Table 1 and Fig. 2J). BP is a product of $\mathrm{BB}$ and $\mathrm{BGR}$, i.e., $\mathrm{BP}=\mathrm{BB} \times \mathrm{BGR}$. $\mathrm{BP}$ of the 3 field investigations shows a negative relationship with temperature simply due to BB increasing offshore but not the BGR.

At the same temperature, recorded $\alpha$ nd $\mathrm{P}^{\mathrm{B}}{ }_{\text {max }}$ values were much higher for summer (Jun-02') samples (Figs. 2F, G; Figs. 3A-B). Many studies have demonstrated that factors other than temperature such as nutrient and light availability as well as species composition, might also affect $\mathrm{P}^{\mathrm{B}}{ }_{\max }$ (Eppley 1972, Cullen et al. 1992). Nutrients (Fig. 2B, $\mathrm{NO}_{3}>1.0 \mu \mathrm{M}$ ) were still detectable even at St. 7 in Jun-02', suggesting this as being a minor chance to be a limiting factor. Light intensity (data not shown) showed positive correlation with $\mathrm{P}^{\mathrm{B}}{ }_{\max }$. This left us to suspect that specific algal compositions with their characteristic initial slope and $\mathrm{P}^{\mathrm{B}}{ }_{\text {max }}$ evolved during different seasons under specific temperature and/or light regimes. We did not conduct phytoplankton species sampling. However, there was evidence (Hwang, Inst Mar Biol, NTOU, personal communication) showing that algal composition changed dramatically with season in this area. The top 3 dominant species during the cold (February-April) season were Nitzschia closterium, $N$. seriata and Trichodesmium thiebautii. The dominant species switched to Chaetoceros curvisetus, C. compressus and Thalassionema nitzschioides during the warm period (May-October).

When compared with other coastal ecosystems, the study area is one with extremely high DOC concentrations with an annual average $>24 \mathrm{gC} \mathrm{m}^{-3}$. There are neither rivers nor a high density of population in vicinity. DOC concentrations were always high without any seasonal 
trend indicating a constant but unclear source. On the other hand, the rest, particularly the rate parameters, recorded at the background stations (Sts. 7 - 8) were not aberrant when compared with those of other estuarine and coastal systems. For example, seasonal maximal CR $\left(\sim 600 \mathrm{mgC} \mathrm{m}^{-3} \mathrm{~d}^{-1}\right.$, Smith and Kemp 1995) and BP ( 160 $\mathrm{mgC} \mathrm{m}^{-3} \mathrm{~d}^{-1}$, Shiah and Ducklow 1994) of the Chesapeake Bay area in fact, were higher than ours albeit that maximal DOC concentrations recorded in the Bay area $\left(9.6 \mathrm{gC} \mathrm{m}^{-3}\right.$, Ducklow et al. 1998) were only $\sim 1 / 4$ of our maximal measurement.

Nevertheless, our high DOC values were by no mean caused by methodological error for two reasons. Firstly, during measuring processes, the DOC machine was repeatedly doublechecked with deep water $(\sim 3000 \mathrm{~m}$ depth $)$ from the South China Sea, and we derived DOC values $\left(\sim 600 \mathrm{mgm}^{-3}\right.$ or $\left.\sim 50 \mu \mathrm{M}\right)$ similar to those of the open ocean. Finally, foaming i.e., the formation of bubbles on the surface water (Barlocher et al. 1988) has been reported at the outlet almost every year since 1980 (Tai-Power, internal report). In laboratory experiments, Shiah et al. (2003b) demonstrated that in the study area, the critical DOC level for sea foam formation was at concentrations $>4,000 \mu \mathrm{M}$ (or $48 \mathrm{gC} \mathrm{m}^{-3}$ ), which was $\sim 40 \%$ higher than our maximal measurement $\left(34 \mathrm{gC} \mathrm{m}^{-3}\right)$. One of the potential sources for this DOC anomaly might come from leakage from a nearby dumpsite, which was buried when constructing the power plant. However, we did not have solid evidence for this deduction.

Without checking the BGR data of the plume system, the positive correlation between BP and PP (Table 1) might be intuitively explained as evidence of bottom-up (organic substrate supply rate) control, as suggested by Cole et al. (1988). However, Table 1 indicated that BGR, an index that has been recognized to be limited by organic substrate supply during warm (i.e., $>25^{\circ} \mathrm{C}$ ) periods or locations (Shiah et al. 2003a and citations therein), varied negatively with PP (and Chl) within the plume. The results of the manipulation and enrichment experiments suggested that bottom-up processes probably seldom limit bacterial growth and community respiration in the study area. As argued by Ducklow and Shiah (1993), bacteria (and other planktoners) could not live on temperature alone without an ample supply of organic substance. A positive temperature response of BGR (and NCR, Table 2) indicated substrate supply probably played minor role in affecting planktoners' metabolism within the plume. In addition, our enrichment experiments (Fig. 4) showed in situ DOC was as labile as dissolved organic matter from animal tissue (zooplankton).

In a review paper, Lomas et al. (2002) showed that the $\mathrm{Q}_{10}$ for $\mathrm{CR}$ in coastal and estuarine ecosystems varied 1.2 - 9.3. Ours showed intermediate values of 1.8 - 3.3 (Table 2). The $\mathrm{Q}_{10}$ value for $\mathrm{BP}$ recorded in the temperature manipulation experiments $\left(\mathrm{Q}_{10}=2.7-3.3\right.$, Table 2$)$ fell at the high end of estuarine systems $\left(\mathrm{Q}_{10}=1.2-4.0\right.$, Lomas et al. 2002 and citation therein). In the Chesapeake Bay (Shiah \& Ducklow 1994) and the shelf of the East China Sea (Shiah et al. 2003a), BGR increased with temperature and reached maxima at ca. $20-25^{\circ} \mathrm{C}$. Interestingly, our data indicated that maximal BGR occurred at temperatures of $\sim 37^{\circ} \mathrm{C}$ (Fig. 4). This might be due to a much more abundant supply of DOC in the study area, leading to substrate limitation on bacterial growth occurring at higher temperatures. This offers another case signifying substrate-temperature interactions on bacterial growth (Pomeroy and Wiebe 2001).

Our findings might offer strong implications for future carbon cycling predictions. As one 
may note, global warming and increasing anthropogenic activities are two inevitable trends. Their potential impacts on the roles coastal ecosystems play as a source or sink of $\mathrm{CO}_{2}$ have been of great concern (Smith and Hollibaugh 1993, del Giorgio et al., 1997, Duarte and Agusti 1998, Williams 1998). Our study provides evidence suggesting that when global warming hits (or which has perhaps begun already), planktonic heterotrophs in some (if not all) coastal systems might adapt to the rising temperatures and keep respiring organic carbon, as long as organic loadings remain high. The warm plume systems in our study serve as ideal "macrocosms" for verifying this.

In summary, the study system was subject to a high degree of anthropogenic disturbance. Thermal effluents from the power plant did have negative impacts on phytoplankton, but seemed to be restricted to a very narrow area within the plume. Autotrophic activity recovered quickly in areas where the bottom depth $>10 \mathrm{~m}$. The high loading of anthropogenic DOC in this system was quite unusual but not unreasonable judging from the systems foaming history. But the standing stocks and rates of autotrophic and heterotrophic organisms behaved pretty much the same as in other ecosystems that receive less DOC input. The positive temperature responses of bacterial growth and community respiration are in line with expectations when organic matter supply rates, either in dissolved or particulate phase, exceed planktoners' growth requirement. Finally, similar heterotrophic Arrhenius type expressions observed in system with contrasting temperature regimes suggest that biogenic emission rates of $\mathrm{CO}_{2}$ in most, if not all, coastal systems might increase exponentially as global temperatures rise, if anthropogenic DOC loadings remain high.

Acknowledgements This research was supported by the Taiwan Power Plant, under grant TPC-048-90-3505-07. RCEC contribution paper \#00085.

\section{REFERENCES}

Barlocher, F., J. Gordon, and R. J. Ireland, 1988: Organic composition of seafoam and its digestion by Corophium volutator (Pallas). J. Exp. Mar. Biol. Ecol., 115, 179-186.

Choi, D. H., J. S. Park, C. Y. Hwang, S. H. Huh, and B. C. Cho, 2002: Effects of thermal effluents from a power station on bacterial and heterotrophic nanoflagellates in coastal waters. Mar. Ecol. Prog. Ser., 229, 1-10.

Cole, J. J., S. Findlay, and M. L.Pace, 1988: Bacterial production in fresh and saltwater ecosystems: a cross-system overview. Mar. Ecol. Prog. Ser., 43, 1-10.

Cullen, J. J., X. Yang, and H. L. MacIntyre, 1992: Nutrient limitation of marine photosynthesis. In: Falkowski P. G., and A. D. Woofheads (Eds.) Primary productivity and biogeochemical cycles in the sea. Plenum, NY. 69-88.

Dai, C. F. 1999: Reef check and coral bleaching. Bull. APEC MRC, 1, 16-18.

Del, Giorgio P. A., J. J. Cole, and A. Cimbleris, 1997: Respiration rates in bacteria exceed phytoplankton production in unproductive aquatic systems. Nature, 385, 148-151.

Duarte, C. M., and S. Agusti, 1998: The $\mathrm{CO}_{2}$ balance of unproductive aquatic ecosystems. Science, 281, 234-236. 
Ducklow, H. W., and F. K. Shiah, 1993: Bacterial production in estuaries. In: Ford, T. (Ed.), Aquatic Microbiology: An Ecological Approach., 11, 261-288, Blackwell, NY.

Ducklow, H. W., G. L. Schultz, P. Raymond, J. Bauer, F. K. Shiah, 1998: Bacterial dynamics in large and small estuaries. In: Bell C. R., M. Brylinsky, and P. Johnson-Green (Eds.). Microbial ecology of estuaries. Atlantic Canada Society for Microbial Ecology, Halifax NS. 105-111.

Eppley, R. W., 1972: Temperature and phytoplankton growth in the sea.Fish Bull., 70, 1063 1085.

Fuhrman, J. A., and F. Azam, 1982: Thymidine incorporation as a measure of heterotrophic bacterioplakton production in marine surface waters: evaluation and field results. Mar. Biol., 66, 109-120.

Hobbie, J. E., R. J. Daley, and S. Jasper, 1977: Use of nuclepore filters for counting bacteria by fluorescence microscopy. Appl. Environ. Microbiol., 33, 1225-1228.

Hung, T. C., C. C. Huang, and K. T. Shao, 1998: Ecological survey of coastal water adjacent to nuclear power plants in Taiwan. Chem. Ecol., 1, 129-142.

Lomas, M. W., P. G. Glibert, F. K. Shiah, and E. Smith, 2002: Microbial processes and temperature in Chesapeake Bay: current relationships and potential impacts of regional warming. Global Change Biol., 8, 51-70.

Pai, S. C., G. C. Gong, and K. K. Liu, 1993: Determination of dissolved oxygen by direct spectrophotometry of total iodine. Mar. Chem., 41, 343-351.

Parsons, T. R., Y. Miata, and M. Lalli, 1984: Amanual of chemical and biological methods for sea water analysis. Pergamon. New York.

Pomeroy, L. R., and W. J. Wiebe, 2001: Temperature and substrates as interactive limiting factors for marine heterotrophic bacteria. Aquat. Microb. Ecol., 23, 187-204.

Redfield, A. C., B. H. Ketchum, and F. A. Richards, 1963: The influence of organisms on the composition of seawater. In: Hill, M. N. (Ed.), The Sea, Vol. 2. Inter-Science, New York, 26-77.

Servais, P., and G. Billen, 1989: Impact of a nuclear power plant on primary production and bacterial heterotrophic activity in the River Meuse at Tihange (Belgium). Arch. Hydrobiol., 114, 415-429.

Shiah, F. K., and H. W. Ducklow, 1994: Temperature regulation of heterotrophic bacterioplankton biomass, production and specific growth rate in the Chesapeake Bay. Limnol. Oceanogr., 39, 1243-1258.

Shiah, F. K., G. C. Gong, and C. C. Chen, 2003a: Seasonal and spatial variation of bacterial production in the continental shelf of the East China Sea: a synthesis of controlling mechanisms and potential roles in carbon cycling. Deep-Sea Res. II, 50, 1295-1309.

Shiah, F. K., S. J. Kao, W. T. Wu, K. Y. Lee, Y. F. Tseng, C. L. Chun, H. W. Lin, and S. S. Song, 2003b: Foam formation and its temporal and spatial variation in the outlet of the power plant. Monthly J. TaiPower's Engineer., 662, 69-76. (Chinese with English abstract)

Smith, E. M., and W. M. Kemp, 1995: Seasonal and regional variations in plankton community production and respiration for Chesapeake Bay. Mar. Ecol. Pro. Ser., 116, $217-$ 231. 
Smith, S. V., and J. T. Hollibaugh, 1993: Coastal metabolism and the oceanic carbon balance. Rev. Geophys., 31, 75-93.

Webb, W. L., M. Newton, and D. Starr, 1974: Carbon dioxide exchange of Alnus rubra: a mathematical model. Oecologia, 17, 281-291.

Williams, P. J. LeB, 1998: The balance of plankton respiration and photosynthesis in the open oceans. Nature, 394, 55-57. 